Dept. of Food Hygiene and Control,

Fac. of Vet. Med., Suez Canal University, Ismailia, Egypt.

\title{
MITOCHONDRIAL CYTOCHROME B GENE AS A TOOL FOR DETECTION OF COMMERCIAL CHEATING OF EGYPTIAN MEAT PRODUCTS WITH PORK
}

(With 2 Tables and 3 Figures)

By

\section{SOAD A.S. ISMAIL; ABEER A.I. HASSANIN* and M.M. OSMAN* \\ * Dept. of Animal Wealth Development, Fac. of Vet. Med., Suez Canal University, Ismailia, Egypt.}

(Received at 25/8/2010)

استخدام جين السيتوكروم ب للكشف عن الغش التجارى لمنتجات اللحوم بلحوم الخنزير

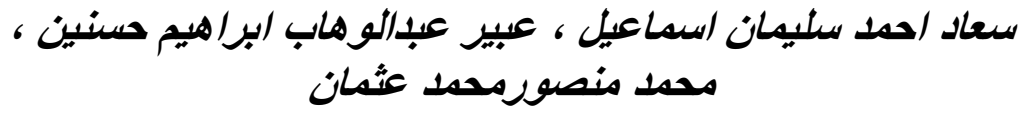

اجريت هذه الدر اسة للكثف عن غش منتجات اللحوم الموجودة بالاسواق المصرية بلحوم

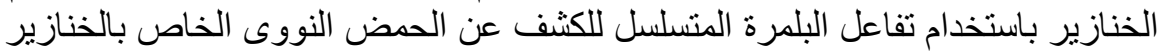

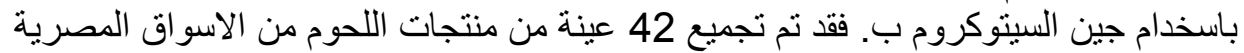

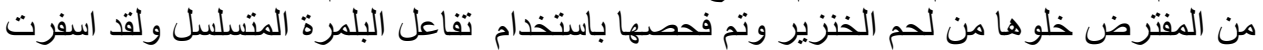

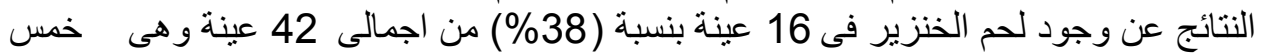

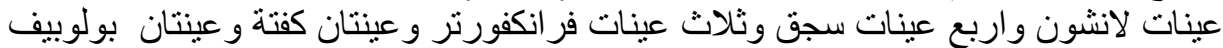

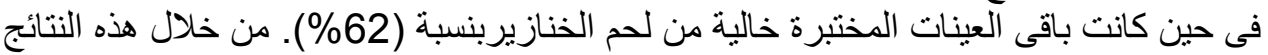

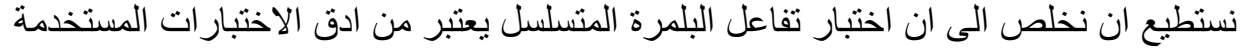

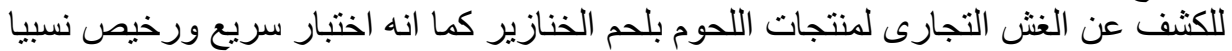

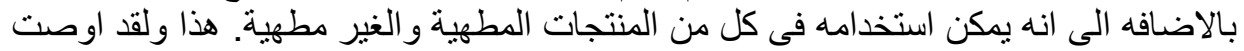

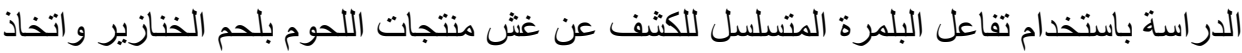

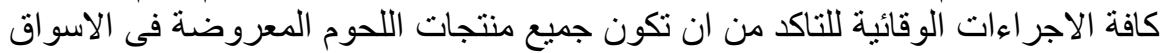
المصرية حلال (خالية من لحم الخنازير ومشتقاته). 
Pork is a potential source for adulteration of higher value meat such as beef and veal. This is objectionable for economic, religious or health reasons. Hence this study was undertaken for detection of commercial adulteration of meat products with pork meat. Forty two samples of meat products were randomly collected from the Egyptian markets. A procine detection methodology based on polymerase chain reaction (PCR) amplification of specific procine fragment (277-bp procine mitochondrial Cytochrome $\mathrm{b}$ gene fragment) was used. The obtained results revealed that 16 samples (38\%) out of 42 samples of processed meat products (5 luncheon, 4 sausage, 3 frankfurter, 2 kofta and 2 corned beef samples) were adulterated with pork meat. From the achieved results in this study it could be concluded that a high percentage $(38 \%)$ of processed meat products sold in the Egyptian markets adulterated with pork meat so it is necessary to establish a systematic food screening methodology for detection of pork meat adulteration in the Egyptian meat products to safeguard the consumer rights. PCR method as a rapid, specific, and sensitive, method has been recommended.

Key words: Meat products, adulteration, pork, PCR, Cytochrome b gene.

\section{INTRODUCTION}

In food industry, quality control and consumer satisfaction require that the origin of materials used in processed food be labeled in the products. Preparation of meat products by mixing meats and fat of different origin is illegal; this kind of adulteration is common in most countries (Alaraidh, 2008).

Adulteration with foreign meats or improper labeling of meat products as Halal while it contained pork or pork fat clearly interfere with the religious prohibitions for Muslims. This is of particular importance not only for religious reasons but also may impose a potential health risk to peoples with allergies to certain proteins. In addition there are consumers who are intolerant to mutton or sensitive to chicken meat and vegetarians (Ong et al., 2007). Therefore, species differentiation of raw materials used for preparation of meat products and detection of animal species in the final products becomes more important as the society progress in step with science.

Consumers rarely have a problem identifying fresh meat when bought from markets. The characteristic color and shape of beef can be distinguished from pork meat whereas processed meat like sausage, 
luncheon and canned foods, poses a problem as these products can not be identified by naked eyes.

After killing of pigs bred in Egypt, consumers in Egypt are afraid from addition of pork meat to the rest of the meat products sold in stores, particularly after the announcement of the slaughtering huge numbers of pigs who arrived so far to nearly 250 thousand pigs.

Currently species identification had been achieved through different available methods rely mainly on protein analysis (Morales et al., 1994) developed an indirect enzyme-linked immunosorbent assay (ELISA) to quantitavily determine raw pork adulteration in beef and chicken. In the same way, Martin et al. (1998) developed a radial immunodiffusion test and ELISA to quantify pork adulteration in raw ground beef.

However proteins loose their biological activity after animal death, and most of them are heat labile and get denaturated by cooking. Thus for species identification and quantification in processed food a DNA method rather than protein analysis would be preferable (Calvo et al., 2001). This method have been proved to be more accurate, fast, easy to use and could work with cooked products because even after subjecting to heat during cooking, the DNA would still be amenable to PCR amplification (Gurdeep.Rastogi et al., 2004).

Some techniques for DNA testing have been developed to identify the species in meat products, such as CAPS (Cleavable Amplified Polymorphic Sequences) (Meyer et al., 1994), Southern blotting by using species-specific satellite DNA as probes (Hunt et al., 1997), RAPD (Random Amplification Polymorphic DNA) fingerprinting (Martinez and Yman 1998; Saez et al., 2004), multiplex PCR (Matsunaga et al., 1999), quantitative intra-short interspersed element PCR (Walker et al., 2003); sequencing the specific gene such as the mitochondrial 12S rRNA (Girish et al., 2004).

Processed meats are likely to contain degraded DNA, therefore mitochondrial DNA (mtDNA) was considered more suitable than nuclear DNA for this analysis. The cytochrome $b$ gene on the mitochondria has been used successfully in species identification and in taxonomic and phylogenetic (Hsing-Mei Hsieh et al., 2005).

In this study, a PCR based methodology was used for detection of pork meat in processed meat products bought from commercial markets in Egypt.

\section{MATERIALS and METHODS}




\section{Collection of Samples:}

Forty two samples of processed meat products, seven samples from each product, were collected from Egyptian markets, these samples were labeled as beef luncheon, sausage, kofta, frankfurter, corned beef, and minced meat. In addition to 3 control samples labeled as pork sausage and luncheon (control positive) obtained from a supermarket selling pork products in Cairo and beef minced meat control negative was obtained from the abattoir of the Faculty of Veterinary Medicine Suez Canal University, Ismailia, Egypt. Sampling was performed monthly over 6 months period from September 2009 to February 2010. All samples were wrapped in polyethylene bags and transported in an icebox to the Animal Wealth Development Laboratory at Suez Canal University, Ismailia, Egypt where they were analyzed.

\section{DNA extraction:}

DNA was extracted using high salt method (http://sciencepark.mdanderson.org/mbcore/protocols.html). Two grams of the frozen tissue were homogenized in $600 \mu \mathrm{l}$ of TNES buffer for 10-15 s. Then $35 \mu \mathrm{l}$ of $20 \mathrm{mg} / \mathrm{ml}$ proteinase $\mathrm{K}$ were added and mixed well. The samples were incubated at $50^{\circ} \mathrm{C}$ overnight, after which $166.7 \mu \mathrm{l}$ of $6 \mathrm{M}$ $\mathrm{NaCl}(\mathrm{NaCl}$ saturated $\mathrm{H} 2 \mathrm{O})$ was added to each sample. Samples were vortexed for $30 \mathrm{~s}$ at maximum speed, and then the samples were Microfuged at full speed $(12-14,000 \mathrm{rpm})$ for 5-10 minutes at room temperature. The supernatant was transferred to fresh tubes. An equal volume of $100 \%$ ethanol was added to each sample, mixed well, and samples were incubated at $-20^{\circ} \mathrm{C}$ for $1 \mathrm{~h}$. Samples were then centrifuged at full speed $(12-14,000 \mathrm{rpm})$ for $10-20$ minutes at $4^{\circ} \mathrm{C}$. The supernatant was poured off and the pellet was washed with $70 \%$ ethanol, dried and finally resuspended in 100-200 $\mu \mathrm{l}$ of sterile distilled water or Tris-EDTA. The DNA concentration was measured by absorbance at $260 \mathrm{~nm}$.

\section{Oligonucleotide primers:}

Two primer sequences, sense (F) and antisense (R), were designed from the published DNA sequence of pork mitochondrial Cytochrome $b$ (accession no. AY830188). The primers sequences are shown in Table 1.

\section{PCR and agarose gel electrophoresis:}

DNA (200 ng) was amplified using 2X PCR master mix (Fermentas, Egypt) composed of 0.05 units $/ \mu$ Taq DNA Polymerase in reaction buffer, $4 \mathrm{mM} \mathrm{MgCl} 2,0.4 \mathrm{mM}$ dATP, $0.4 \mathrm{mM}$ dCTP, $0.4 \mathrm{mM}$ dGTP and $0.4 \mathrm{mM}$ dTTP. PCR was carried out in a final reaction volume of $25 \mu \mathrm{l}$ containing the DNA sample $(1 \mu \mathrm{l})$, forward and reverse primers $(1 \mu 1$ each), PCR master mix $(12.5 \mu \mathrm{l})$ and distilled water $(9.5 \mu \mathrm{l})$. PCR done using TC-25/H thermal cycler, The cycle conditions for PCR were as 
follows: initial denaturation at $95^{\circ} \mathrm{C}$ for 10 minutes followed by 40 cycles of $95^{\circ} \mathrm{C}$ for $45 \mathrm{sec}, 50^{\circ} \mathrm{C}$ for $45 \mathrm{sec}$ and $72^{\circ} \mathrm{C}$ for $90 \mathrm{sec}$, then $72^{\circ} \mathrm{C}$ for 10 minutes for further extension (Hsing-Mei Hsieh et al., 2005). In order to confirm the amplification of the target sequence and the pork specifity of the oligonucleotide pork, the PCR product was eleectrophoresed on $1 \%$ agarose gel of $0.5 \mathrm{x}$ TBE buffer and made visible by staining with ethidium bromide at a constant voltage of 100 for 1 hour. The resulting fragments were visualized by UV transillumination (Slimeline ${ }^{\mathrm{TM}}$ series).

\section{RESULTS}

Table 1: Oligonucleotide primers used in PCR amplification of pork mitochondrial cytochrome $b$.

\begin{tabular}{|c|c|c|}
\hline Primer & Nucleotide Sequence & Nucleotide location \\
\hline F & 5'- TACTATTCTCACCAGACCTACT-3' & $728-749$ \\
R & 5'- TAGTGTAATGAGGTCTGCTACT-3' & $984-1005$ \\
\hline
\end{tabular}

Table 2: Frequency distribution of pork meat in the examined meat products samples.

\begin{tabular}{|l|c|c|c|c|}
\hline $\begin{array}{r}\text { Meat products(N=49) } \\
7 \text { from each product }\end{array}$ & \multicolumn{2}{|c|}{$\begin{array}{c}\text { Positive samples } \\
\text { (adulterated with pork meat) }\end{array}$} & \multicolumn{2}{c|}{$\begin{array}{c}\text { Negative samples } \\
\text { (not adulterated ) }\end{array}$} \\
\hline Luncheon & F & $\%$ & F & $\%$ \\
\hline Sausage & 4 & 11.9 & 2 & 4.8 \\
\hline Kofta & 2 & 9.5 & 3 & 7 \\
\hline Frankfurter & 3 & 4.8 & 5 & 12 \\
\hline Corned beef & 2 & 4.8 & 5 & 12 \\
\hline Minced meat & 0 & 0 & 7 & 16.7 \\
\hline Total & 16 & 38 & 26 & 62 \\
\hline
\end{tabular}




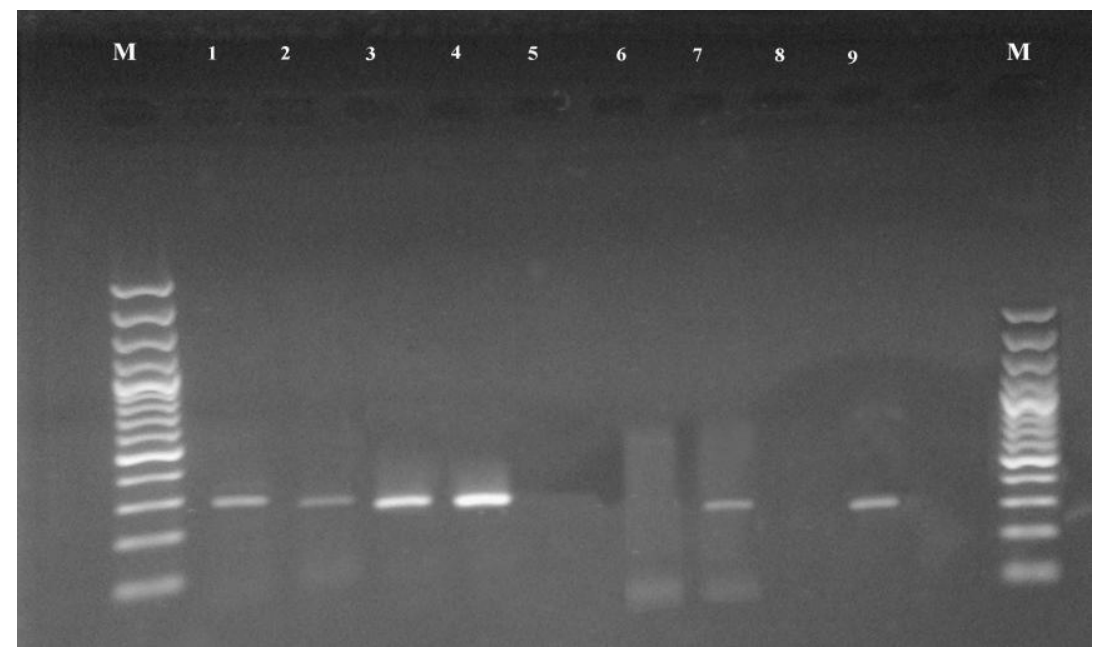

Fig. 1: Gel electrophoresis showing the detection of the specific $277 \mathrm{bp}$ porcine mitochondrial Cytochrome $b$ gene in the examined meat products from the first market. Lane 1: kofta, lane 2: luncheon, lane 3: pork suasage, lane 4: pork launchon, lane 5: luncheon, lane 6: minced meat, lane 7: sausage, lane 8: frankfurter, lane 9: corned beef, lane 10: beef minced meat.

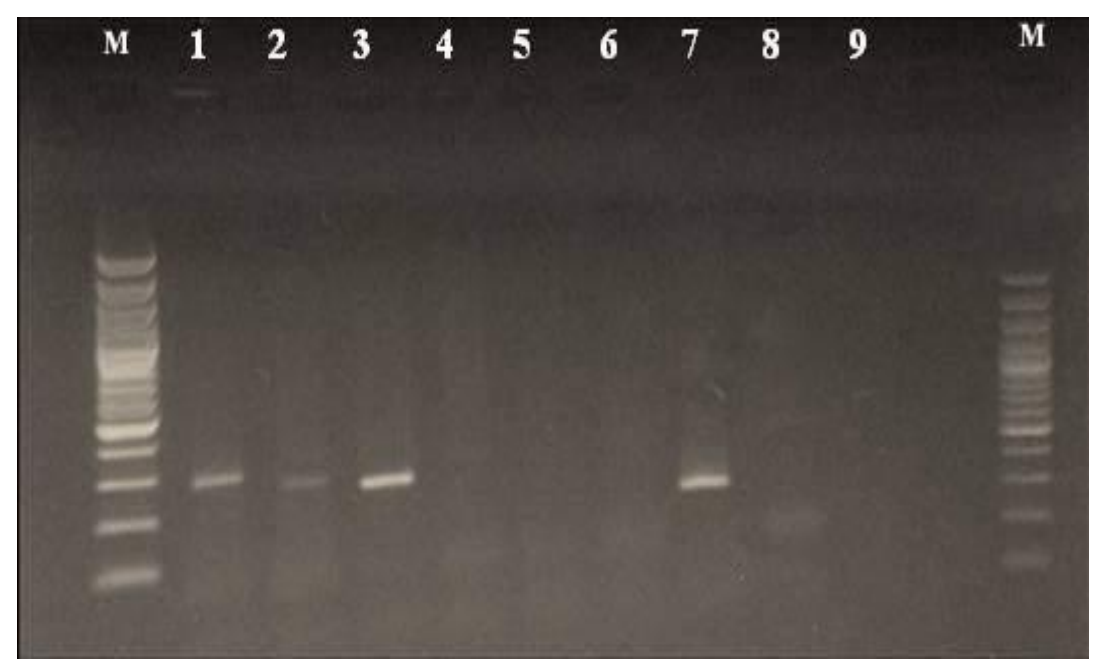

Fig. 2: Gel electrophoresis showing the detection of the specific $277 \mathrm{bp}$ porcine mitochondrial Cytochrome $b$ gene in the examined meat products from the second market. lane 1: corned beef, lane 2: kofta, lane 3: pork suasage, lane 4: luncheon, lane 5: sausage, lane 6: minced meat, lane 7: frankfurter, lane 8: frankfurter and lane 9 beef minced meat. 


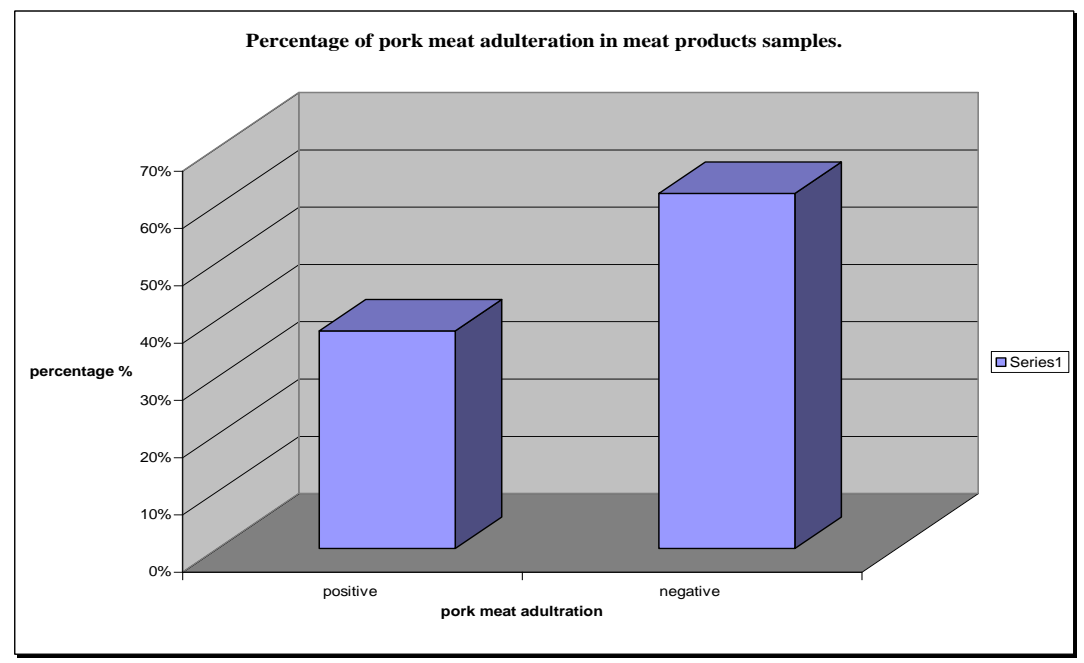

Fig. 3: Percentage of pork meat adulteration in meat products samples

\section{DISCUSSION}

Food products have been adulterated since food is sold, species that achieve a good price in the market have been a target for deceivers to substitute or adulterate with similar but cheaper species. In the case of meat products this is objectionable. Identification of pork in meat products has several important applications in the food industry, not only to detect falsely labeled products but also for economic, religious and health reasons.

Egypt's 80-million populations consist mainly of Muslims, whose religion forbids them from eating pork meat, as well as an estimated six to 10 percent Christian Copts who may eat pig meat.

For the identification of animal species, it is preferable to detect DNA; DNA carries an organism's total genetic information and has to be stable .It is identical in all cell types of an organism; therefore it does not matter whether the DNA is extracted from blood, muscles, liver or any other tissue. The information content of DNA is greater than that of the protein, for these reasons protein based methods are being replaced by methods based in nucleic acid (Brodman, 2002).

Polymerase chain reaction offers analytical approach based on nucleic acid to identify species. (Kocher et al., 1989) have shown that some highly conserved regions on the mitochondrial Cytochrome $b$ gene are suitable for species identification. PCR technology allows amplification of specific regions of DNA facilitating the detection of genetic differences between species (Brown, 2001; Abdel Rahman and Ahmed, 2007). 
In this study, the amplification of the species specific 277-bp procine mitochondrial Cytochrome $b$ gene fragment using specific primers showed specific detection of pork meat in the examined samples.

The two oligonucleotide primers (forward and reverse) were used to amplify the species-specific 277-bp porcine mitochondrial Cytochrome b gene fragment showing that these primers are able to detect porcine adulteration in non-pork food products as established in Figure 1. The fragments are shown in lane 1, beef kofta, lane 2, beef luncheon, (pork suasage sample in lane 3 and pork luncheon sample in lane 4, as positive controls) beef sausage sample in lane 7 and corned beef sample in lane 9 . Whereas lanes 5, 6, and 8 containing other meat products (beef luncheon from another company, minced meat, and frankfurter respectively) in addition to minced meat sample lane 10 (negative control) did not show any existence of the porcine mitochondrial Cytochrome $b$ gene fragment.

Figure 2 shows the amplification of the 277- bp porcine mitochondrial Cytochrome $b$ gene fragment in beef samples collected from another market, the fragments are shown in lane 1, corned beef, lane 2, beef kofta, lane 3, "pork suasage", lane 7, beef frankfurter' whereas lanes $4,5,6$, and 8 containing beef luncheon, beef sausage, minced meat, and frankfurter from different sources respectively did not show any existence of the porcine mitochondrial Cytochrome b gene fragment. Lane 9 minced beef control negative.

The choice of the target gene and the design of the primers have a great impact on the sensitivity and the specifity of a detection system (Soichi Tanabe et al., 2007). It is well known that very sensitive PCR assays can be established when the primer target is a multicopy gene such as a mitochondrial gene (Holzhauser et al., 2006). In this study the porcine Cytochrome $b$ region of mitochondrial DNA as the target to detect pork meat adulteration in commercial meat product has been chosen.

The obtained results as shown in Figure 3 revealed that high percentage $(38 \%)$ of the examined meat products samples from Egyptian markets contains pork meat. This is attributed to the decision taken by the Egyptian government to slaughter all swine herds in an effort to prevent swine flu spreading, since the appearance of swine flue in May 2009. Estimates of the number of slaughtered pigs during this period ranged from 250,000 to 400,000 . This huge numbers explains the fear of consumers in Egypt form mixing of pig meat with meat products.

The results shown in Table 2 revealed that the positive samples which adulterated with pork meat were luncheon $(11.9 \%)$, sausage $(9.5 \%)$, kofta (4.8\%), frankfurter (7\%) and corned beef (4.8) whereas the examined samples of minced meat were negative (not adulterated by pork meat). The 
comminuted meat products could easily mixed with different types of meat and this could not be detected by naked eye.

The existence of pork meat in meat products makes it a potential health threat to consumers due to the microbial and parasitic infections transmitted through pork, non-communicable diseases attributed to the consumption of pork, risk factors in relation to chronic degenerative diseases, in addition to hazards in the pig breeding establishments (http://www.firstchurchoftheinternet.org/pdf/PigMeat.pdf). The most important and definitely proven hazards connected with the consumption of pork are the two zoonotic parasites trichinellosis and systemic cysticercosis. Both infections can be life threatening and their prevention requires difficult measures. (Schenone, et al., 1982). Of the noncommunicable diseases attributable to pork consumption (food) allergy and liver cirrhosis have been shown to occur (Nanji et al., 1985).

Also, consumption of pork and lard can give rise to hyperlipidaemi constituting a risk factor in cardiovascular diseases (WHO, 1982). Furthermore, high pork and lard consumption in a low fiber diet would have a correlation with high incidence of cancer of the colon (http://www.firstchurchoftheinternet.org/pdf/PigMeat.pdf).

These facts highlight the need to establish a systematic food screening methodology for detection of pork meat adulteration in the Egyptian meat products. The study also demonstrates the need for more vigilant inspection and stricter enforcement of applicable public health laws by food monitoring authorities to prevent illegal addition of pork meat to other meat products.

It is apparent from the obtained results that the use of simple DNA test is of particular value in identifying the animal species used in processed meat and in investigating the situation about the fraudulent misdescription of food contents on product labels in Egyptian markets.

In summary, a PCR method could be applicable for the specific detection of pork in processed food. Since this method is rapid, specific, and sensitive, and the information from this test could support the law enforcement to decrease the fraudulent misdescription situation.

\section{REFERENCES}

Abdel-Rahman, S.M. and Ahmed, M.M. (2007): Rapid and sensitive identification of buffalos, cattles and sheeps milk using species specific PCR and PCR -RELP techniques. Food Control. 18: 1246-1249.

Abdussalam, Health aspects of the consumption of pig meat (pork). (http://www.firstchurchoftheinternet.org/pdf/PigMeat.pdf) 
Alaraidh, I.A. (2008): Improved DNA Extraction Method for Porcine Contaminants, Detection in Imported Meat to The Saudi Market. Saudi Journal of Biological Sciences. 15 (2): 225-229.

Brodman, P. (2002): Species identification development and validation of species identification. Ph.D. thesis, University of Basel.

Brown, P. (2001): Bovine spongiform encephalopathy and variant Creutzfeldt-Jakob disease. Br. Med. J. 322: 841-844.

Calvo, J.H.; Zaragoza, P. and Osta, R. (2001): Technical note, A quick and more sensitive method to identify pork in processed and unprocessed food by PCR amplification of a new specific D fragment .J. Animal sci. 79 (8): 2108-2112.

Girish, P.S.; Anjaneyulu, A.S.R.; Viswas, K.N.; Anand, M.; Rajkumar, N.; Shivakumar, B.M. and Bhaskar, S. (2004): Sequence analysis of mitochondrial $12 \mathrm{~S}$ rRNA gene can identify meat species. Meat Sci. 66: 551-6.

Gurdeep Rastogi; Mahesh Dharne; Alul Bhardo, V.S.; Pandav, S.V.; Ghumatkar, R.; Krishnamurthy, M.S. Patol and Yogesh, S. Shouche (2004): Species determination and authentication of meat samples by mitochondrial 12SrRNA gene sequence analysis and conformation sensitive gel electrophoresis. Current Science. Vol 87: 9-10.

Hsing-Mei Hsieh; Chin-Cheng Tsai; Li-Chin Tsai; Hslao-Ling Chlang; Nu-En Huang; Rocky Tai-Ping Shih; Adrian Linacre and James Chun-I Lee (2005): Species identification of meat products using the Cytochrome b gene. Forensic Science Journal. 4: 29-36.

Hunt, D.J.; Parkes, H.C. and Lumley, I.D. (1997): Identification of the species of origin of raw and cooked meat products using oligonucleotide probes. Food Chem. 60: 437-42.

Holzhauser, T.; Stephan, O. and Vieths, S. (2006): Polymerase chain reaction (PCR) methods for the detection of allergenic foods. In "Detecting Allergens in food" CRC Press, Boca Raton, pp. 125-143.

Ong, S.B.; Zuraini, M.I.; Jurin, W.G.; Cheah, Y.K.; Tunung, R.; Chai, L.C.; Haryani, Y.; Ghazali, F.M. and Son, R. (2007): Meat molecular detection: Sensitivity of polymerase chain reactionrestriction fragment length polymorphism in species differentiation of meat from animal origin. Asean Food Journal. 14(1): 51-59.

Martinez, I. and Yman, I.M. (1998): Species identification in meat products by RAPD analysis, Food Res. Intern. 31: 459-66. 
Martin, D.R.; Chan, J. and Chin, J.Y. (1998): Quantitative evaluation of pork adulteration in raw and ground beef by radial immunodiffuse and Enzyme Linked immunosorbent assay. J. of Food Protection. 61 (12): 1686-1690.

Matsunaga, T.; Chikuni, K.; Tanabe, R.; Muroya, S.; Shibata, K.; Yamada, J. and Shinmura, $Y$. (1999): A quick and simple method for the identification of meat species and meat products by PCR assay. Meat Sci. 51: 143-8.

Meyer, R.; Candrian, U. and Luthy, J. (1994): Detection of pork in heated meat products by the polymerase chain reaction. J. AOAC Int. 77: 617-622.

Morales, P.; Garcia, T.; Gonzalez, I.; Martin, R.; Sanz, B. and Hhrnandez, P.E. (1994): Monoclonal antibody detection of procine meat. J. of Food Protection. 57: 146-149.

Nanji, Amin A. and French, S.W. (1985): Relationship between pork consumption and cirrhosis. Lancet. 681-683.

Saez, R.; Sanz, Y. and Toldra, F. (2004): PCR-based fingerprinting techniques for rapid detection of animal species in meat products. Meat Sci. 66: 659-65.

Schenone, H.; Villaroel, F.; Rojas, A. and Ramirez, R. (1982): "Epidemiology of human cysticercosis in Latin America." In: FLIESSER, A. et al. (edts.). "Cysticercosis: present state of knowledge and perspectives." New York: Academic Press, 1982, pp. 25-38.

Soichi Tanabe, Eiji Miyauchi, Akemi Muneshige, Kazuhiro Mio, Chikara Sato and Masahiko Sato (2007): PCR method of detecting pork in foods for verifying allergen labeling and for identifying hidden pork ingredients in processed food. Bioscience, Biotechnology and Biochemstry. 71(7): 1663-1667.

Walker, J.A.; Hughes, D.A.; Anders, B.A.; Shewale, J.; Sinha, S.K. and Batzer, M.A. (2003): Quantitative intra-short interspersed element PCR for species-specific DNA identification. Anal. Biochem. 316: 259-69.

Who, (1982): Prevention of coronary heart disease."report of a WHO expert committee," Techn. Rep. Ser. No. 678, 
Assiut Vet. Med. J. Vol. 56 No. 127 October 2010 
Assiut Vet. Med. J. Vol. 56 No. 127 October 2010 
Assiut Vet. Med. J. Vol. 56 No. 127 October 2010 